\title{
The Effect of Health Education about Menstruation on Psychological Readiness of Pre-Adolescent Girls in Facing Menarche
}

\author{
Luh Putu Widiastini, I Gusti Agung Manik Karuniadi \\ Institute of Health Science Bina Usada Bali, Indonesia \\ vedya_galz@yahoo.com
}

\begin{abstract}
Adolescence is a period of transition between age and adulthood, where growth spurts occur, secondary sex-features arise, fertility occurs and better psychological and cognitive conditions, in which girls are marked by the emergence of menstruation (menarche). Menarche is the first menstrual period that occurs during puberty in a woman. In some cases, this accelerated growth can affect a woman's psychological, changes that can occur include or mistakes that often occur. Information that really can be used to improve the ability of young women.Health efforts that can be done to increase knowledge to learn the correct information about menarche for young women, one of which is health promotion through health education. The purpose of this study was to find out the Psychological Impression of Pre-Adolescent Girls (the fifth grade students) Facing Menarche at SDN 02 Sanur, Denpasar. The benefits of this research are as input as a service profession that further enhances service and attention to screening programs for teenagers specifically about menarche. The pre-experimental study was designed with one group pre-test and posttest.This study was involved 23 sample of pre-Adolescent girls (the fifth grade students) of SDN 2 Sanur, Badung, from July - August 2018. The data on pre-Adolescent girls about psychological readinessin facing menarche was assessed before and after intervention (health education) were collected statistically then analyzed. The results of the study concluded that there was a positive effect of health education about menstruation on psychological readinessin facing menarche. This study obtained complete results before and after treatment with a p value of $0,000(<0,05)$. The results of this study are expected to be one of the considerations and evaluations for teachers and principals in programming the adolescent health education for their students.
\end{abstract}

Keywords: Pre-Adolescent girls, menarche, health education

Received July, 25, 2019; Revised August 24, 2019; Accepted September 13, 2019 


\section{STRADA Jurnal Ilmiah Kesehatan}

DOI: $10.30994 /$ sjik.v8i2.216

ISSN: 2252-3847 (print); 2614-350X (online)

Vol.8 No.2. November 2019. Page.69-73

\section{BACKGROUND}

Adolescence is a period of transition between childhood and adulthood, where growth spurts occur, secondary sex characteristics arise, fertility occurs and psychological and cognitive changes occur (Soetjiningsih, 2010). This period is often referred to as puberty which lasts between the ages of 10-19 years. Adolescence consists of early adolescence (10-13 years), middle adolescence (14-16 years), and late adolescence (17-19 years) (Tarwoto, et al, 2010). Whereas according to Efendy (2007) adolescents are interpreted as a period of development of the transition between childhood and adulthood which includes biological, cognitive and social emotional changes. It usually starts around the age of 10-13 years and ends between the ages of 18-22 years.

According to Tarwoto, Dkk (2010), the characteristics of primary sexuality in adolescents are distinguished by gender, namely men and women. Teenage boys are characterized by the functioning of the reproductive organs, namely by the presence of wet dreams which generally occur at the age of 10-15 years. While for young women it is marked by menstrual events (menarche).

Menarche is the first menstrual period that occurs during puberty in a woman. The normal age of menarche is 12 years and is said to be early menarche if the age is under 12 years. The tendency of young women to get their first menstrual period (menarche) is influenced by 2 factors, namely internal factors and external factors. Internal factors usually occur due to a hormonal imbalance that is born from birth. This condition is also triggered by external factors, such as food (especially food), the modern environment and the level of prosperity of the people in an area (Waryana, 2010). According to Kartini's research, 2015 with the title "Attitudes of Young Women in Facing Puberty Physical Change" with a sample of 92 people stated $64.1 \%$ of respondents were negative in dealing with physical changes in puberty. This problem is generally influenced by lack of or incorrect information about menstruation. Therefore young women need information about the menstrual process and health during menstruation.

Correct information is expected to increase knowledge so as to be able to change the attitudes of young women. Attitudes are not born from birth, but are formed and studied throughout development. The attitude is able to change according to the environment and emotional transition. The emotional transition period is still experienced by teenagers to find their true identity.

Health efforts that can be implemented to increase knowledge to obtain correct information about menarche for young women, one of which is health promotion through health education .Health education is an effort to improve the health status of individuals and communities because the process makes people able to improve control and improve their health, the feeling is expected that people, groups and individuals can obtain knowledge about good health. Extension has many methods, one of them is the lecture method. The lecture method is suitable for high and low education targets.

Based on preliminary studies through interviews with Principals and Teachers of School Health Unit (UKS) at SDN 02 Sanur, Denpasar, said that the fifth grade students had never received health education on reproduction health especially menstruation, and still often found students crying when menarche and menstrual disorders. While from the results of interviews with 10 female students in the fifth grade students, there were 2 (20\%) students who were ready to face menstruation and $8(80 \%)$ students who were still afraid and not ready to face menarche. This research is aim to find out "The Effect of Health education 


\section{STRADA Jurnal Ilmiah Kesehatan}

DOI: $10.30994 /$ sjik.v8i2.216

ISSN: 2252-3847 (print); 2614-350X (online)

Vol.8 No.2. November 2019. Page.69-73

About Menstruation on Psychological Readiness of Pre-Adolescent Girls (The Fifth grade students) Facing Menarche at SDN 02 Sanur, Denpasar".

\section{OBJECTIVE}

This study aimed to find out the Psychological Impression of Pre-Adolescent Girls (the fifth grade students) Facing Menarche.

\section{METHODS}

Pre-experimental research was design with one group pre test and post test design. The questionnaire was filled in 2 times before 01 and after 02 treatments. Differences 01 and 02 are assumed to be the extension effects given. There is no control group (Notoatmodjo, Soekidjo. 2010). Respondents in this study were prepubertal girls (The Fifth grade students) of SDN 2 Sanur, Badung, which numbered 23 people, which were held in July - August 2018

\section{RESULTS}

\section{Univariate Analysis}

Characteristics of Respondents by age

\begin{tabular}{lll}
\hline Variable & $\mathrm{n}$ & $\%$ \\
\hline 9 years old & 16 & 69,6 \\
10 years old & 6 & 26,1 \\
11 years old & 1 & 4,3 \\
\hline Total & 23 & 100 \\
\hline
\end{tabular}

Based on the data in table above, out of 23 respondents, the highest age was 9 years at $69.6 \%$, compared to 10 years of age at $26.1 \%$, age 11 at $4.3 \%$.

Normality test

\begin{tabular}{llll}
\hline Variable & \multicolumn{3}{l}{ Kolmogorov-Smirnov } \\
\cline { 2 - 4 } & Statistic & df & Sig. \\
\hline Readiness pre & .183 & 23 & .045 \\
\hline Readiness post & .143 & 23 & .200 \\
\hline
\end{tabular}

Based on Table above, it can be seen that for all variables it is abnormally distributed because the $\mathrm{p}$ value at Kolmogorov-Smirnov>0.05. This means that the score of the readiness variable is abnormally distributed. So that it can be tested with Wilcoxon.

\section{Bivariate Analysis}

The Differences Readiness before and after treatment

\begin{tabular}{|c|c|c|c|}
\hline Category & $\begin{array}{l}\text { Mean } \\
\text { Rank }\end{array}$ & $\begin{array}{c}\text { Sum of } \\
\text { Rank }\end{array}$ & $\mathrm{Z}$ \\
\hline Psychological Readiness before and after treatment & 11.34 & 181.50 & -3.487 \\
\hline
\end{tabular}




\section{STRADA Jurnal Ilmiah Kesehatan}

DOI: $10.30994 /$ sjik.v8i2.216

ISSN: 2252-3847 (print); 2614-350X (online)

Vol.8 No.2. November 2019. Page.69-73

\section{DISCUSSION}

Menarche is the first menstrual period that occurs during puberty in a woman. The normal age of menarche is 12 years and is said to be early menarche if the age is under 12 years. The tendency of young women to get their first menstrual period (menarche) is influenced by 2 factors, namely internal factors and external factors. Internal factors usually occur due to a hormonal imbalance that is born from birth. This condition is also triggered by external factors, such as food (especially food), the modern environment and the level of prosperity of the people in an area (Waryana, 2010).

Changes that can be caused by menarche are increased hormones that result in changes in the body shape of young women to be faster, especially the extremities, and the body gradually gets a shape according to the sex. The speed of growth is caused by estrogen. Other effects of estrogen are the growth of internal genetalia, external genetalia, and secondary sex characteristics. In puberty internal genetalia and external genetalia gradually grew to reach the shape and nature of adulthood. In some cases, the acceleration of growth can affect the psychology of young women, reactions that can occur include anxiety or fear which is often reinforced by the desire to reject the physiological process (Kartono, 2006). This problem is generally influenced by lack of or incorrect information about menstruation. Therefore young women need information about the menstrual process and health during menstruation. Correct information is expected to increase knowledge so as to be able to change the attitudes of young women. Attitudes are not born from birth, but are formed and studied throughout development. The attitude is able to change according to the environment and emotional transition. The emotional transition period is still experienced by teenagers to find their true identity. Health efforts that can be implemented to increase knowledge to obtain correct information about menarche for young women, one of which is health promotion through health education .Health education is an effort to improve the health status of individuals and communities because the process makes people able to improve control and improve their health, the feeling is expected that people, groups and individuals can obtain knowledge about good health. Extension has many methods, one of them is the lecture method. The lecture method is suitable for high and low education targets. The researcher conducted this study to find out the effect of health education on menstruation on psychological readiness of prepubertal young women (fifth grade students) facing menarche at SDN 02 Sanur, Denpasar using total sampling. The results of the distribution of questionnaires pre and post in terms of Psychological Preparedness of Pre-Adolescent Young Women (the fifth grade students) Facing Menarche, most of the respondents experienced an increase in psychological readiness in facing menarche. Based on statistical testing using Wilcoxon to analyze the differences in psychological readiness in the group before and after being given treatment obtained a value of $\mathrm{p}<0.05$ so that it can be interpreted giving health education about menstruation can increase Psychological Preparedness of Pre-Adolescent Girls (the fifth grade students) Facing Menarche The results of the study have proven that the provision of health education about menstruation can increase Psychological Preparedness of Pre-Adolescent Girls (the fifth grade students) Facing Menarche.

\section{CONCLUSION}

There is an Influence of Health education About Menstruation on Psychological Readiness of Pre-Adolescent Young Women (the fifth grade students) Facing Menarche at SDN 02 Sanur, Denpasar with a value of $p 0,000(<0,05)$. The results of this study are expected to be 


\section{STRADA Jurnal Ilmiah Kesehatan}

DOI: $10.30994 /$ sjik.v8i2.216

ISSN: 2252-3847 (print); 2614-350X (online)

Vol.8 No.2. November 2019. Page.69-73

a material consideration and evaluation for teachers and principals in programming teenage reproductive health education for their students

\section{REFERENCES}

Efendy, F. (2007). Koping Adaptasi Menarche Sebagai Strategi Peningkatan Kesehatan Reproduksi Remaja. Monday 12 Maret 2018. http://www.ferryefendy.blogspot.com.

Kartono, K. (2006). Psikologi Wanita Jilid I Mengenal Gadis Remaja dan Wanita Dewasa. Bandung : Mandar Maju.

Notoatmodjo, \& Soekidjo. (2010). Metodologi Penelitian kesehatan.Jakarta: Rineka Cipta.

Saputro, H., \& Talan, Y. O. (2017). Pengaruh Lingkungan Keluarga Terhadap Perkembangan Psikososial Pada Anak Prasekolah. Journal Of Nursing Practice, 1(1), 1-8. https://doi.org/10.30994/jnp.v1i1.16

Soetjiningsih. (2010). Tumbuh Kembang Remaja dan Permasalahannya. Jakarta: Sagung Seto.

Suhita, B. M., Dwianggimawati, M. S., Saputro, H., Kusumawati, P. D., \& Wardani, L. K. (2019). Coping Mechanism of Students Facing the Competency Exams Reviewed from the Factors Influence in Surya Mitra Husada Health College Kediri. Indian Journal of Public Health Research \& Development, 10(1), 1204-1208. https://doi.org/10.5958/0976-5506.2019.00219.5

Tarwoto, dkk, (2010). Kesehatan remaja problem dan Solusinya. Jakarta: Salemba Medika.

Waryana. (2010). Gizi Reproduksi. Yogyakarta: Pustaka Rihama 